\title{
Enzyme heterozygosity and growth in rainbow trout: genetic and physiological explanations
}

\author{
MOIRA M. FERGUSON \\ Department of Zoology, University of Guelph, Guelph, Ontario, Canada NIG 2WI
}

\begin{abstract}
The possibility of whether the association between enzyme heterozygosity and body size (fork length) is consistent among rainbow trout (Oncorhynchus mykiss) with different degrees of relationship and is affected by fish age was determined. Six-month-old full-sibs and progeny groups from five and 13 parents of each sex do not show the positive associations between multilocus heterozygosity and fork length which are detectable in larger pooled gamete matings $\left(250^{\circ} \times 250^{\circ}\right)$. Moreover, the relationship between heterozygosity at single loci and fork length is inconsistent among families. These data suggest that chromosomal segments, marked by the enzyme loci, are responsible for the phenotypic effects (associative overdominance). Fish age affects both the strength and direction of the association between multilocus heterozygosity and fork length; the association is positive in 6-month-old rainbow trout but is weaker, negative, or differs between the sexes in fish at 1 year. Moreover, the strength of the relationship changes over time in repeated measurements on the same fish. A decline in growth of larger and more heterozygous fish, because of precocial sexual maturation, may partially explain the changing relationship between multilocus heterozygosity and fork length. Sexually mature males are significantly more heterozygous than immature males and show significantly reduced recent growth rates as measured by white muscle RNA concentration. However, females, who rarely mature at 1 year, show significantly higher recent growth rates. Thus, heterozygosity is differentially associated with the allocation of energy resources into somatic and reproductive tissue in male and female rainbow trout.
\end{abstract}

Keywords: associative overdominance, fish, growth-heterozygosity, RNA concentration, sexual maturation.

\section{Introduction}

The identity of the genetic loci responsible for associations between enzyme heterozygosity and characters related to fitness, and the genetic mechanism whereby they act (dominance or overdominance), is generally unknown (Mitton \& Grant, 1984; Allendorf \& Leary, 1986; Zouros, 1987; Zouros \& Foltz, 1987). Both the enzyme loci (direct involvement explanation, Zouros \& Foltz, 1987) and chromosomal segments marked by the enzyme loci (associative overdominance, Zouros \& Foltz, 1987) have been proposed as responsible for the phenotypic correlations (Koehn et al., 1988; Zouros et al. 1988, respectively). According to the associative overdominance hypothesis, the enzyme loci are in gametic disequilibrium with overdominant loci with effects on fitness or more homozygous individuals at enzyme loci have increased the probability of being homozygous for deleterious recessive alleles at loci randomly spread throughout the genome due to either gametic-phase disequilibrium or inbreeding (Houle, 1989).

The associative overdominance and direct involvement hypothesis can be tested because they make contrasting predictions on the consistency of the heterozygosity/fitness association among the progeny of different crosses (Danzmann et al., 1986; Mallet et al., 1986; Leary et al., 1987; Zouros et al., 1988; Zouros \& Mallet, 1989; Leberg et al., 1990). Under the direct involvement of the enzyme loci, the relationship between specific genotypes and relative fitness should be consistent among progeny groups (among families, pooled gamete versus families) due to the consistent metabolic roles of the gene products. In contrast, 
associative overdominance predicts that the heterozygosity/fitness association might differ among progeny groups depending upon breeding structure and linkage associations between enzyme loci and deleterious genes (Zouros \& Foltz, 1987; Houle, 1989).

Multilocus heterozygosity is positively associated with body size among the progeny of pooled gamete matings in both the Arlee and Eagle Lake hatchery strains of rainbow trout (Oncorhynchus mykiss) (Danzmann et al. 1987, 1988). Surprisingly, a negative relationship was detected amongst older fish (about 1 year) derived from the self-sustaining natural population in the Ganaraska River, Ontario (Ferguson 1990). The first experiments reported here test the two general hypotheses for the detected associations between heterozygosity and body size by determining whether consistent associations are detectable among pooled gamete matings produced from fewer parents and full-sibs.

The direct involvement and associative overdominance hypotheses do not, however, address the differences in the direction of the multilocus heterozygosity/body size association observed among strains of rainbow trout sampled at different ages. One explanation is that the detection of the correlation is affected by precocial sexual maturation in males; females rarely mature at 1 year (Ferguson, 1990). This hypothesis was tested by examining the heterozygosity-size correlation in rainbow trout sampled at different ages and comparing the heterozygosity of precociously mature and immature males.

\section{Materials and methods}

\section{Fish}

The progeny of adult rainbow trout collected from the Ganaraska River, Port Hope, Ontario, or a derived hatchery stock, were used in all experiments. The hatchery stock was initiated in the early 1980s and has been maintained with large effective population sizes $(>500)$ at the Ontario Ministry of Natural Resources Normandale Fish Culture Station (Ferguson et al., 1991). The Ganaraska River population is a relatively large self-sustaining stock and over 10,000 fish have been counted during the spawning run in recent years. The natural and hatchery sources can be considered a single strain, at least within the context of the present study, because no significant differences in allele frequencies have been detected between them (Ferguson \& Ihssen, 1991; Ferguson et al., 1991).

Six, pooled gamete crosses were made by addition of equal volumes of sperm from several males (premixed), with equal volumes of eggs from the same number of females (also premixed prior to combination with sperm). Two progeny groups were produced from hatchery fish (A14 - 11 March 1987; B35 - 16 March 1988) and four progeny groups with wild fish (A200 - 15 April 1987; C14, C15, C16 - 20 April 1989). All progeny groups were produced by combining gametes of 25 females and 25 males except for $\mathrm{C} 15$ and $\mathrm{C} 16$ where 13 and five fish of each sex were used, respectively. Twelve full-sib families were produced on 15 April 1987 from the same rainbow trout used to produce A200.

All progeny groups were reared at the University of Guelph in raw well water, ranging from 6 to $12^{\circ} \mathrm{C}$ depending upon the season. The fish were fed to excess with commercial trout food and their photoperiod was adjusted monthly to follow ambient conditions. The ages of all fish represent days since fertilization.

\section{Electrophoresis}

Genotypes at eight polymorphic loci were determined in all fish with horizontal starch gel electrophoresis (Allendorf et al., 1977) or cellulose acetate gel electrophoresis (Hebert \& Beaton, 1989). The protein products resolved on high $(>8)($ bGlua, Pgm2, Sod, G3 pl, and $G l 1)$ and low $\mathrm{pH} .(7-8)$ (Idh2, Idh 3,4 , and $M d h 3,4)$ buffers were scored on cellulose acetate and starch, respectively. Multilocus heterozygosity was expressed as the observed number of heterozygous loci per fish. Two pairs of loci $(I d h 3,4 ; M d h 3,4)$ are duplicated and share alleles (isoloci) and therefore it is difficult to assign a specific allele to a given locus. Therefore, each duplicated pair was considered a single tetrasomic locus in all analyses where fish with a single electromorph were designated homozygotes while fish with two or more electromorphs were considered heterozygotes.

\section{Body size and growth}

Fork length, measured from the tip of the snout to the fork of the tail (nearest millimetre), was used as an estimate of body size. RNA concentration $(\mu \mathrm{g} / \mathrm{g}$ wet tissue) and an RNA:DNA ratio were used as estimates of recent growth as the amount of RNA in white muscle is positively associated with direct measures (Bulow, 1987; Ferguson \& Danzmann, 1990). Previous studies with Ganaraska rainbow trout have shown that RNA concentration is a more sensitive indicator of recent growth (measured by changes in body size) than RNA:DNA ratio (Ferguson \& Danzmann, 1990). The concentrations of RNA and DNA were measured in white muscle according to the flourometric method of Karsten \& Wollenberger (1972) as modified by Ferguson \& Drahushchak (1989). 


\section{Statistics}

The Pearson product-moment correlation coefficient $(r)$ was used as a measure of association between the number of heterozygous loci per fish and growth (fork length, RNA, RNA:DNA ratio). The contribution of specific loci to the heterozygosity-growth relationship within a specific progeny group was determined with multiple linear regression where each locus was considered an independent variable and fork length the dependent variable (see Koehn et al., 1988 for an example). Heterozygotes at a particular locus are assigned a value of 1 and homozygotes a value of 0 . Thus, the contribution and significance of a specific locus can be determined by the significance and direction of the partial regression coefficient. Parametric ANOVAS were used to determine if mean numbers of heterozygous loci per fish were significantly different among progeny groups. Finally, non-parametric $t$-tests (Wilcoxon two sample) were used to determine if mature and immature males differed in growth and heterozygosity because these data do not meet parametric assumptions.

\section{Results}

\section{Progeny groups}

The association between the number of heterozygous loci per fish and fork length is not consistent among 6-month-old progeny groups with different degrees of relationship (Table 1). Multilocus heterozygosity is significantly and positively associated with fork length in the pooled gamete mating $\mathrm{C} 14$. In contrast, progeny produced from pooled matings with fewer parents of each sex (C15, C16) show no significant association.

Table 1 Multiple regression between heterozygosity at eight enzyme loci (independent variables) and fork length $(\mathrm{cm})$ (dependent variable) in 6-month-old Ganaraska rainbow trout with different degrees of relationship. The association $(r$, Pearson product-moment correlation coefficient) between multilocus heterozygosity and fork length is also given

\begin{tabular}{|c|c|c|c|c|c|c|c|c|c|}
\hline \multirow{2}{*}{$\begin{array}{l}\text { Progeny } \\
\text { group }\end{array}$} & \multicolumn{8}{|l|}{ Locus } & \multirow[b]{2}{*}{$r$} \\
\hline & bGlua & $G 3 p$ & $G l 1$ & $I d h 2$ & $\operatorname{Idh} 3,4$ & $M d h 3,4$ & $\operatorname{Pgm} 2$ & Sod & \\
\hline \multicolumn{10}{|c|}{ Pools $\left(25 \% \times 25 ठ^{\prime}\right)$} \\
\hline A200 & NS & NS & NS & NS & NS & NS & NS & NS & 0.196 \\
\hline $\mathrm{C} 14$ & NS & + & NS & NS & NS & NS & + & NS & $0.343^{*}$ \\
\hline \multicolumn{10}{|c|}{ Pools $\left(\mathrm{C} 15: 13 \propto \times 130^{\circ} ; \mathrm{C} 16: 5 \% \times 5 \sigma^{\circ}\right)$} \\
\hline $\mathrm{C} 15$ & NS & NS & $\mathbf{M}$ & NS & - & NS & NS & NS & 0.066 \\
\hline $\mathrm{C} 16$ & NS & $\mathbf{M}$ & NS & - & NS & NS & NS & NS & 0.181 \\
\hline \multicolumn{10}{|c|}{ Families $\left(1 \% \times 10^{\prime}\right)$} \\
\hline A37 & $\mathbf{M}$ & $\mathbf{M}$ & M & NS & + & - & $\mathbf{M}$ & + & $0.350^{*}$ \\
\hline A39 & NS & $\mathbf{M}$ & $\mathbf{M}$ & NS & NS & + & $\mathbf{M}$ & $\mathbf{M}$ & 0.052 \\
\hline A41 & NS & $\mathbf{M}$ & $\mathbf{M}$ & NS & $\mathbf{M}$ & NS & NS & NS & -0.018 \\
\hline A42 & $\mathbf{M}$ & NS & $\mathbf{M}$ & $\mathbf{M}$ & $\mathbf{M}$ & $\mathbf{M}$ & NS & NS & -0.053 \\
\hline A43 & NS & $\mathbf{M}$ & $\mathbf{M}$ & + & $\mathbf{M}$ & NS & $\mathbf{M}$ & + & $0.408^{* *}$ \\
\hline A46 & NS & M & $\mathbf{M}$ & NS & NS & NS & NS & NS & -0.156 \\
\hline A48 & NS & M & NS & $\mathbf{M}$ & NS & $\mathbf{M}$ & + & $\mathrm{M}$ & 0.230 \\
\hline A49 & NS & $\mathbf{M}$ & $\mathbf{M}$ & NS & - & $\mathbf{M}$ & NS & NS & -0.150 \\
\hline A50 & NS & $\mathbf{M}$ & NS & $\mathrm{M}$ & - & $\mathbf{M}$ & $\mathbf{M}$ & NS & -0.018 \\
\hline A52 & NS & NS & $\mathbf{M}$ & - & $\mathbf{M}$ & NS & $\mathbf{M}$ & NS & $-0.352^{*}$ \\
\hline A53 & $\mathbf{M}$ & $\mathbf{M}$ & $\mathbf{M}$ & $\mathbf{M}$ & $\mathbf{M}$ & $\mathbf{M}$ & NS & NS & 0.235 \\
\hline A54 & NS & $\mathbf{M}$ & $\mathbf{M}$ & $\mathbf{M}$ & NS & NS & NS & $\mathrm{M}$ & 0.103 \\
\hline
\end{tabular}

Sample sizes: $\mathrm{A} 200=43, \mathrm{C} 14=44, \mathrm{C} 15=46, \mathrm{C} 16=39, \mathrm{~A} 37=39, \mathrm{~A} 39-\mathrm{A} 54=40$.

- partial $t=P<0.05$, Homo $>$ Het.

+ partial $t=P<0.05$, Het $>$ Homo.

NS partial $t=P>0.05$.

$\mathrm{M}=$ locus monomorphic in progeny group.

${ }^{*} P<0.05,{ }^{* *} P<0.01$. 
Moreover, progeny from 12 full-sib families show no consistent relationship between multilocus heterozygosity and fork length. Significant positive correlations are detectable in two families and a negative relationship in a third. Overall, the correlation coefficients are negative in six families and positive in six families.

The relationship between heterozygosity at specific loci and fork length is inconsistent among families and pooled progeny groups when each locus is treated as an independent variable in multiple regression (Table 1). For three loci $(I d h 2, I d h 3,4$, and $M d h 3,4)$, the partial regression coefficients are significantly positive in one family and significantly negative in at least one other. Thus, heterozygotes at a specific locus are larger than homozygotes in some families and the reverse is true in others.

\section{Fish age}

The strength and the direction of the relationship between multilocus heterozygosity and fork length in the progeny of pooled gamete matings of rainbow trout changes over time (Fig.1). A significant positive correlation was detected in C14 sampled at 193 days. Older fish show a weaker or negative relationship between multilocus heterozygosity and fork length. Fish from A200 (sexes combined) show a significant positive association at 291 days. This relationship is not significant in the same fish sampled at $376,473,465$, and 604 days. Similarly, no relationship was detected in

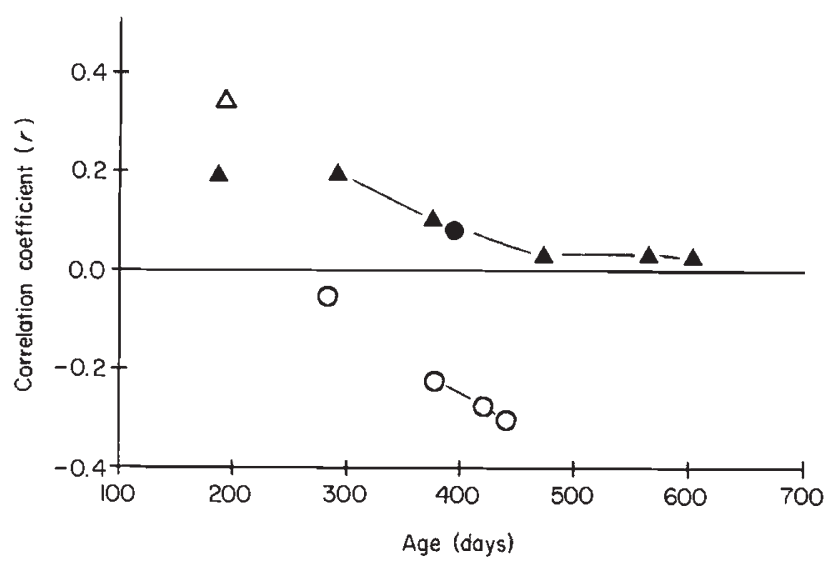

Fig. 1 Pearson product-moment correlation coefficients $(r)$ between the number of heterozygous loci per fish and fork length in the progeny of four pooled gamete matings $(25 \%$ and $25{ }^{\circ}$ ) of Ganaraska rainbow trout and sampled between 187 and 604 days from fertilization (sexes combined). Linked points represent repeated measurements on the same fish. Sample sizes (age): (O) A14 (283) = 40, A14 (378$441)=75,(\bullet) B 35(395)=137,(\Delta) \mathrm{C} 14(193)=44$, (৯) A200 $(187)=43$, A200 $(291-604)=165$.
A14 at 283 days and B35 at 395 days. Significant negative associations were detected from repeated measurement of A14 (same fish) at 378, 421, and 441 days.

Repeated measurements of A200 and A14 indicate that the association between multilocus heterozygosity and fork length differs between the sexes over time (Fig. 2). Females from A200 show a significant positive association at 291 days. However, the relationship is not significant at 376, 473, 565, and 604 days. Males do not show any significant association on any sampling day. In A14, females show no significant association at 378,421 , and 441 days while males show significantly negative associations on all 3 days. On all sampling dates with both progeny groups (eight comparisons), males show more negative correlation coefficients between multilocus heterozygosity and fork length than females (correlation coefficients displaced downwards in Fig. 2).

RNA concentration is a more sensitive indicator of the subtle and complex changes in growth at 1 year than fork length. As previously mentioned, no signifi-
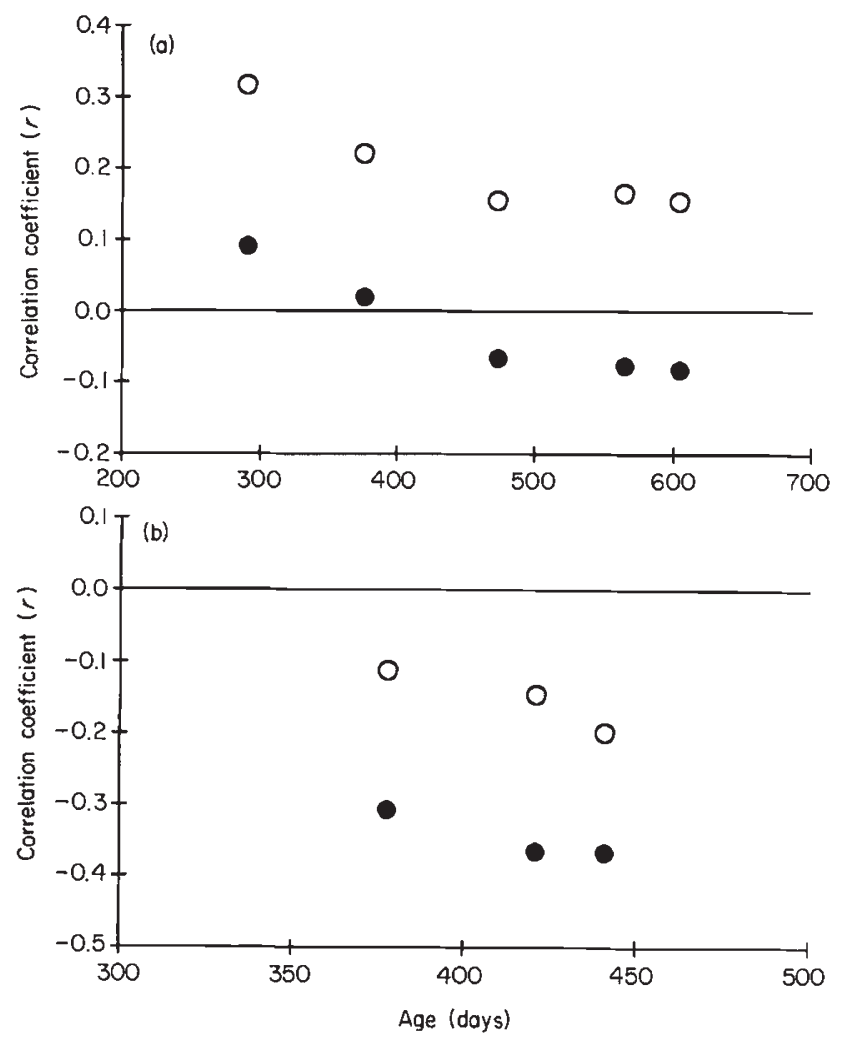

Fig. 2 Pearson product-moment correlation coefficients $(r)$ between the number of heterozygous loci per fish and fork length in 70 female (O) and 95 male (-) rainbow trout from (a) A200 measured between 291 and 604 days from fertilization and in 35 female and 40 male progeny from (b) A14 measured at 378,421 , and 441 days. 
association between multilocus heterozygosity and recent growth, as measured by RNA concentration in white muscle, was detected in females but not in males (Fig. 3).

The importance of precocial sexual maturation to the heterozygosity-growth correlation was examined in a more direct experiment with B35 sampled at 395 days. The predictions were tested that precociously mature males are more heterozygous and show lower recent growth than immature males. Spermiated males have significantly higher numbers of heterozygous loci per fish and show lower recent growth rates (muscle RNA and RNA:DNA ratio) than immature males (Table 2). Spermiated and immature males do not differ significantly in fork length.

\section{Discussion}

\section{Progeny groups}

The association between multilocus heterozygosity and fork length differs among progeny groups with dif-
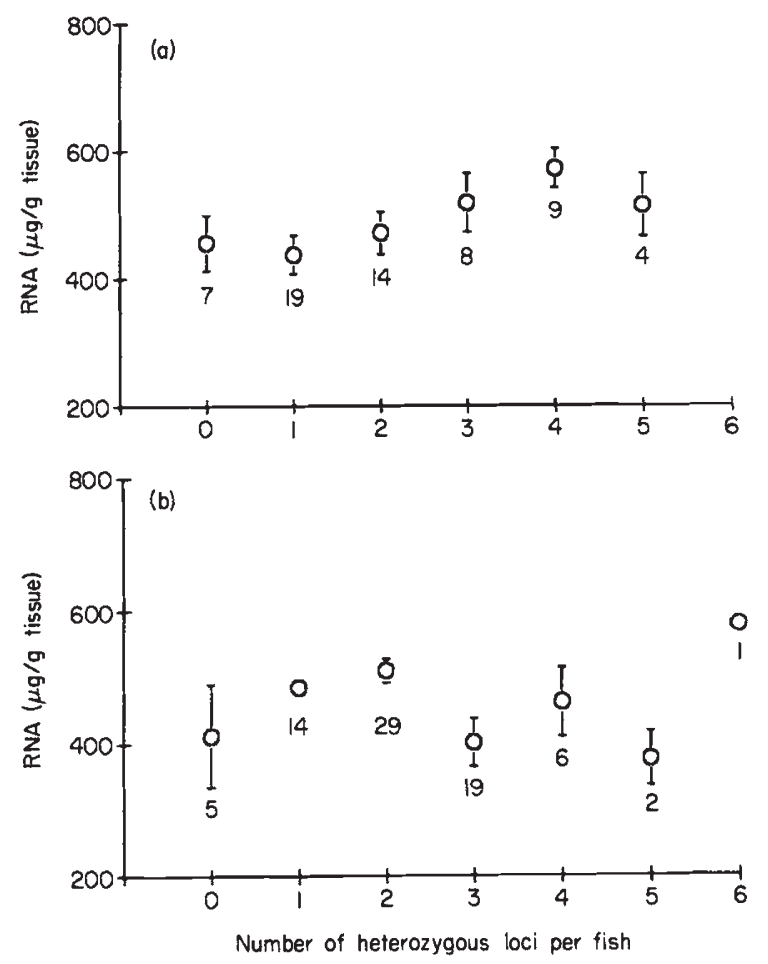

Fig. 3 The relationship between the number of heterozygous loci per fish and recent growth as measured by RNA concentration in white muscle of (a) female and (b) male progeny of a pooled gamete mating (B35) at 395 days. The vertical bars represent the standard error of the mean. The numbers below the bars indicate the number of fish sampled in each heterozygosity class. Females: $r=0.326$, d.f. $=59$, $P<0.01$; Males: $r=0.073$, d.f. $=74, P>0.05$. ferent degrees of relationship. Pooled gamete crosses sampled at 6 months show positive associations whereas full-sib families, and pooled gamete crosses with lower numbers of parents show no consistent associations. This inconsistency among progeny groups is not compatible with the direct involvement of the enzyme loci but suggests that chromosomal segments marked by the enzyme loci are responsible for the phenotypic correlations (associative overdominance).

A variety of genetic conditions could account for the phenotypic correlations under associative overdominance (Houle, 1989). The enzyme loci could be closely linked to the marked chromosomal segments such that occasional cross-overs between the enzyme locus and the unknown segment would lead to a change in the direction between genotype and fitness value. The differences among families in the direction of the association at single loci is consistent with this explanation. Alternatively, electrophoretic homozygosity could be correlated with homozygosity for recessive deleterious genes because of either inbreeding or gameticphase disequilibrium. The lack of association in families and detectable associations in pooled gamete crosses is compatible with this second hypothesis. To distinguish between these possibilities is one of the greatest challenges to students of this problem, however, recent advances in molecular biology make it possible to evaluate the fitness effects of nucleotide variation within chromosomal segments tightly linked to the enzyme loci.

These conclusions assume that interactions among enzyme and marked chromosomal segments in different genetic backgrounds are responsible for the inconsistency among cross types. However, reduced polymorphism in progeny groups produced with low numbers of parents could militate against detection of

Table 2 Mean (SEM) concentrations of nucleic acids in white muscle $(\mu \mathrm{g} / \mathrm{g}$ wet weight of tissue), fork length $(\mathrm{cm})$ and number of heterozygous loci per fish in mature and immature male rainbow trout at 395 days (from fertilization) from a pooled gamete mating (B35)

\begin{tabular}{lccl}
\hline Measure & Mature & Immature & Significance \\
\hline Heterozygosity & $2.88(0.52)$ & $2.15(0.14)$ & $*$ \\
Fork length & $14.5(0.5)$ & $13.7(0.4)$ & \\
DNA & $78(7)$ & $101(3)$ & $* *$ \\
RNA & $301(44)$ & $485(13)$ & $* * *$ \\
RNA:DNA & $3.88(0.50)$ & $5.13(0.28)$ & $*$ \\
$n$ & 8 & 68 & \\
\hline
\end{tabular}

${ }^{*} P<0.05,{ }^{* *} P<0.01 ;{ }^{* * *} P<0.001$ (1 tail) Wilcoxon twosample test. 
cant association between multilocus heterozygosity and fork length was detected in B35. However, a positive correlations in such groups. This proposed explanation cannot, however, account for the observed inconsistencies in the direction of the correlations both at the multilocus and single locus levels. Furthermore, the lack of significant correlation in $\mathrm{C} 15$ and $\mathrm{C} 16$ is not the result of lower numbers of heterozygous loci relative to the larger pooled mating $(\mathrm{C} 14)$ because no significant differences in the mean number of heterozygous loci per fish were detected between them (One-way ANOvA; $F_{2,126}=1.411 ; P=0.248$ ).

Despite the acknowledged importance of protein polymorphism in evolutionary processes, the role of the enzyme loci in selective processes remains controversial (e.g. Zouros et al., 1988; Koehn et al., 1988; Houle, 1989; Gaffney et al., 1990; Koehn, 1990; Zouros, 1990). The dichotomy is in part due to the different approaches that laboratories have used to address the problem. For instance, studies where the direct involvement and associative overdominance hypotheses have been tested by examining the inconsistency in the heterozygosity-fitness correlation among progeny groups have provided support for associative overdominance (Beaumont et al., 1985; Foltz \& Chatry, 1986; Danzmann et al., 1986; Mallet $e t$ al., 1986; Danzmann et al., 1988; Zouros et al., 1988; Leberg et al. 1990; present study). As an exception, Leary et al. (1987) argued that the strength and direction of the correlation between multilocus heterozygosity and the number of asymmetric meristic characters is as strong among full-sibs as it is among individuals randomly sampled from populations of salmonid fishes (Leary et al., 1984). In contrast, physiological studies (Koehn \& Shumway, 1982; Garton et al., 1984; Mitton et al., 1986; Hawkins et al., 1986, 1989; Koehn et al., 1988) have provided mechanistic biochemical connections between enzyme phenotypes and fitness. These studies generally argue that the phenotypic effects are determined by heterozygosity at the enzyme loci rather than marked chromosomal segments because the metabolic basis for the correlations derive from differences in net energy status. Thus, given the dichotomy of approaches and conclusions (Koehn, 1990; Zouros, 1990), it is conceivable that the identity of the loci responsible for the fitness correlations will only be established with experiments that encompass both approaches.

\section{Fish age}

Fish age affects both the strength and direction of the correlation between multilocus enzyme heterozygosity and fork length in pooled gamete crosses of rainbow trout. Positive associations were detected in fish at 6 months but the association is either weak, nondetectable, or the sexes differ in older fish. These data complement previous studies with this species; Danzmann et al. $(1987 ; 1988)$ observed positive associations in fish less than 6 months old while Ferguson (1990) observed negative associations in older fish.

These data are consistent with the hypothesis that sexual maturation of more heterozygous individuals affects the association. Correspondingly, more heterozygous individuals would have faster growth rates before the spawning season, resulting in precocial maturation and slower growth at the onset. Thus, the detection of negative correlations in males and the significant differences in heterozygosity between mature and immature males suggests that sexual maturation has important influences on the heterozygosity-growth correlation. More heterozygous males presumably divert finite energy reserves into gamete production earlier, resulting in the detectable declines in recent growth.

A corollary of the maturation hypothesis is that the sexes should differ in the relative effect because of differential maturation at 1 year. Because females rarely mature so young, they should not show equivalent declines in growth as males resulting in the maintenance of the heterozygosity-growth correlation. The detection of positive associations between heterozygosity and recent growth (RNA concentration) in females from B35 supports this idea. However, despite a lack of sexual maturation, females still showed a decline in the heterozygosity-fork length correlation. This suggests that other factors affect the allocation of resources into somatic and reproductive tissue in homozygotes and heterozygotes.

Declines in the heterozygosity-fork length correlation with age and sex-specific differences were detected in both progeny groups where repeated measurements were taken over time. However, the progeny groups differed in the magnitude of the decline and qualitative differences in the relationship were detectable. There are many explanations for this difference, including factors that affect growth and maturation rates (and chance). For example, Ferguson (1990) observed that a significant negative association between multilocus heterozygosity and fork length was observed only among those fish fed excess rations and not those designed to promote low growth. This apparent variation in the magnitude of the heterozygosity-fork length correlation in relation to environmental factors might suggest that such results are too phenotypically labile to be of much biological significance. However, studies with another species of salmonid fish, indicate that sexspecific associations between heterozygosity and body 
size are not an artifact of laboratory rearing. Mature male brook trout, Salvelinus fontinalis, from Mykiss Lake, Algonquin Provincial Park, Ontario show significant negative associations between multilocus heterozygosity and fork length whereas heterozygosity was positively associated with fork length in females (Liskauskas \& Ferguson, 1991). Differences in growth rates prior to sexual maturation and differential allocation of energy towards gametic and somatic tissue have been proposed as mechanisms for the different relationships between body size and heterozygosity in male and female brook trout.

Studies with other species, especially marine invertebrates, have shown that the heterozygosity-growth correlation changes with age (Rodhouse et al., 1986; Zouros \& Foltz, 1987). No direct relationship between gonad development and heterozygosity, however, has been detected (Zouros et al., 1988). Thus, the significantly higher heterozygosity in mature relative to immature male rainbow trout provides some of the most direct evidence that heterozygosity is associated with gonadal development in animals.

The dependence of the heterozygosity-growth correlation on fish age has important implications for studies where the objective is to determine the genetic mechanisms of such correlations. For instance, the lack of detectable and consistent correlations within full-sib families sampled at reproductive age could be taken as evidence for associative overdominance even though the results could be explained by maturation effects. A careful choice of sampling time and concomitant examinations of pooled gamete progeny would partially alleviate this problem.

\section{Acknowledgements}

I would like to thank L. Drahushchak, R. Frank, and M. Milicevic for their technical assistance and the Ontario Ministry of Natural Resources for providing the experimental fish. Financial support was provided by grants from the Natural Sciences and Engineering Research Council of Canada, and the Ontario Ministry of Natural Resources Renewable Resources Research grant programme and a College of Biological Sciences Summer Research Fellowship to M. Milicevic.

\section{References}

ALLENDORF, F. W. AND LEARY, R. F. 1986. Heterozygosity and fitness in natural populations of animals. In: M. E. Soulé (ed.). Conservation Biology: The Science of Scarcity and Diversity. Sinauer, Sunderland, MA, pp. 57-76.

ALLENDORF, F. W., MITCHELL, N., RYMAN, N. AND STAHL, G. 1977. Isozyme loci in brown trout (Salmo trutta L.): Detection and interpretation from population data. Hereditas, 86 , 179-190.
BEAUMONT, A. R., GOSLING, E. M., BEVERIDGE, C. M. BUDD, M. D. AND BURNELL, G. M. 1985. Studies of heterozygosity and size in the scallop Pecten maximus (L). In: P. E. Gibbs (ed.), Proceedings of the 19th European Marine Biology Symposium, Plymouth, England. Cambridge University Press. Cambridge, UK, pp. 243-245.

BULOw, F. J. 1987. RNA-DNA ratios as indicators of growth in fish. In: R. C. Summerfelt and G. E. Hall (eds), The Age and Growth of Fish. The Iowa State University Press, Ames, pp. 45-64.

DANZMANN, R. G. FERGUSON, M. M. AND ALLENDORF, F. W. 1986. Does enzyme heterozygosity influence developmental rate in rainbow trout? Heredity, 56, 417-425.

DANZMANN, R. G., FERGUSON, M. M. AND ALLENDORF, F. W. 1987. Heterozygosity and oxygen consumption rate as predictors of growth and developmental rate in rainbow trout. Physiol. Zool., 60, 211-220.

DANZMANN, R. G., FERGUSON, M. M. AND ALLENDORF, F, w. 1988. Heterozygosity and components of fitness in rainbow trout. Biol. J. Linn. Soc., 33, 285-304.

FERGUSON, M. M. 1990. Heterozygosity and growth of rainbow trout reared at two rations. Biol. J. Linn. Soc., 40, 215-227.

FERGUSON, M. M. AND DANZMANN, R. G. 1990. RNA:DNA ratios as estimates of growth in rainbow trout held at different temperatures. Can. J. Zool., 68, 1494-1498.

FERGUSON, M. M. AND DRAHUSHCHAK, L. R. 1989. Effects of tissue collection and storage methods on nucleic acid determinations in white muscle of fishes. Trans. Am. Fish. Soc., 118, 709-713.

FERGUSON, M. M. AND IHSSEN, P. E. 1991. Distribution and phenotypic correlates of variation of enzyme coding loci in rainbow trout (Oncorhynchus mykiss) from the lower Laurentian Great Lakes. Can. J. Fish. Aquat. Sci., 48, 1308-1315.

FERGUSON, M. M., IHSSEN, P. E. AND HYNES, J. D. 1991. Are cultured stocks of brown trout and rainbow trout genetically similar to their source populations? Can. J. Fish. Aquat. Sci., (in press).

FOLTZ, D. W., AND CHATRY, M. 1986. Genetic heterozygosity and growth rate in Louisiana oysters (Crassostrea virginica). Aquaculture, 57, 261-269.

GAFFNEY, P. M., SCOTT, T. M., KOEHN, R. K. AND DIEHL, W. A. 1990. Interrelationships of heterozygosity, growth rate and heterozygote deficiencies in the coot clam, Mulinia lateralis. Genetics, 124, 687-699.

GARTON, D. W., KOEHN, R. K. AND SCOTT, T. M. 1984. Multiple-locus heterozygosity and the physiological energetics of growth in the coot clam, Mulinia lateralis, from a natural population. Genetics, 108, 445-455.

HAWkINS, A. J. B., BAYNE, B. L. AND DAY, A. J. 1986. Protein turnover, physiological energetics and heterozygosity in the blue mussel, Mytilus edulis: The basis of variable agespecific growth. Proc. Roy. Soc. Lond. B, 229, 161-176.

HAWKINS, A. J. B., BAYNE, B. L., DAY, A. M., RUSIN, J. AND WORRALL, C. M. 1989. Genotype-dependent interrelations between energy metabolism, protein metabolism and fitness. In: J. S. Ryland and P. A. Tyler (eds), Reproduction, Genetics, and Distributions of Marine Organisms. Olsen and Olsen, Fredensborg, Denmark, pp. 383-392. 
HEbert, P. D. N. AND BeATon, M. 1989. Cellulose Acetate Gel Electrophoresis. Helena Laboratories, Beaumont, TX.

HOULE, D. 1989. Allozyme-associated heterosis in Drosophila melanogaster. Genetics, 123, 789-801.

KARSTEN, U. AND WOLLENBERGER, A. 1972. Determination of DNA and RNA in homogenized cells and tissue by surface fluorometry. Anal. Biochem., 46, 135-158.

xOEHN, R. K.1990. Heterozygosity and growth in marine bivalves: comments on the paper by Zouros, RomeroDorey, and Mallet (1988). Evolution, 44, 213-216.

KOEHN, R. K., DIEHL, W. J. AND SCOTT, T. M. 1988. The differential contribution by individual enzymes of glycolysis and protein catabolism to the relationship between heterozygosity and growth rate in the coot clam, Mulinia lateralis. Genetics, 118, 121-130.

KOEHN, R.K., AND SHUMWAY, S. E. 1982. A genetic/physiological explanation for differential growth rate among individuals of the oyster Crassostrea virginica (Gmelin). Mar. Biol. Lett., 3, 35-42.

LEARY, R. F., ALLENDORF, F. W. AND KNUDSEN, K. L. 1984. Superior developmental stability of heterozygotes at enzyme loci in salmonid fishes. Am. Natur., 124, 540-551.

LEARY, R. F., ALLENDORF, F. W. AND KNUDSEN, K. L. 1987. Differences in inbreeding coefficients do not explain the association between heterozygosity at allozyme loci and developmental stability in rainbow trout. Evolution, 41, 1413-1415.

LEBERG, P. L., SMITH, M. H. AND RHODES, O. E. 1990. The association between heterozygosity and growth of deer fetuses is not explained by effects of the loci examined. Evolution, 44, 454-458.

LISKAUSKAS, A. P. AND FERGUSON, M. M. 1991. Genetic variation and fitness: a test in a naturalised population of brook trout (Salvelinus fontinalis). Can. J. Fish. Aquat. Sci., (in press).

MALLET, A. L., ZOUROS, E., GARTNER-KEPKAY, K. E., AND FREEMAN, K. R. 1986. Genetics of growth in the blue mussel: Family and enzyme-heterozygosity effects. Mar. Biol., 92, 475-482.

MITTON, J. B., CAREY, C. AND KOCHER, T. D. 1986. The relation of enzyme heterozygosity to standard and active oxygen consumption and body size of tiger salamanders, Ambystoma tigrinum. Physiol. Zool., 59, 579-582.

MITTON, J. B. AND GRANT, M. C. 1984. Associations among protein heterozygosity, growth rate, and developmental homeostasis. Ann. Rev. Ecol. Syst., 15, 479-499.

RODHOUSE, P. G., MCDONALD, J. H., NEWELL, R. I. E. AND KOEHN, R. X. 1986. Gamete production, somatic growth and multiplelocus enzyme heterozygosity in Mytilus edulis L. Mar. Biol., 90, 209-214.

zOUROS, E. W. 1987. On the relation between heterozygosity and heterosis: An evaluation of the evidence from marine mollusks. In: M. C. Rattazzi, J. G. Scandalios, and G. S. Whitt (eds), Isozymes Current Topics in Biological and Medical Research, Vol. 15, Alan Liss, New York, pp. 255-270.

zouros, E 1990. Heterozygosity and growth in marine bivalves: response to Koehn's remarks. Evolution, 44, 216-218.

zOUROS, E. W. AND FOLTZ, D. 1987. The use of allelic isozyme variation for the study of heterosis. In: M. C. Rattazzi, J. G. Scandalios, and G. S. Whitt (eds), Isozymes: Current Topics in Biological and Medical Research, Vol. 13, Alan Liss, New York, pp. 1-59.

ZOUROS, R., AND MALLET, A. L. 1989. Genetic explanations of the growth/heterozygosity correlation in marine mollusks. In: J. S. Ryland and P. A. Tyler (eds), Reproduction, Genetics and Distributions of Marine Organisms. Proceedings of the XXIII European Marine Biology Symposium. Olsen and Olsen, Fredensborg, Denmark. pp. 317-324.

ZOUROS, E., ROMERO-DOREY, M. AND MALLET, A. L. 1988. Heterozygosity and growth in marine bivalves: Further data and possible explanations. Evolution, 42, 1332-1341. 